\title{
PENGEMBANGAN MEDIA PEMBELAJARAN VIDEO ANIMASI BERBASIS SPARKOL VIDEOSCRIBE PADA TEMA 7 SUBTEMA 2 SISWA KELAS IV SD NEGERI 030355 PARRATUSAN
}

\author{
Eva Betty Simanjuntak, Astria Hospital \\ Surel: evabettysimanjuntak@gmail.com
}

\begin{abstract}
This study aims to produce sparkol videoscribe-based animated video learning media, to determine the feasibility of sparkol videoscribe-based animated video learning media and to determine the effectiveness of using Sparkol videoscribe-based animated video learning media on Theme 7 Subtheme 2 Grade IV Students of SD Negeri 030355 Parratusan. This research and development was carried out using the ADDIE model (Analysis, Design, Development, Implementation and Evaluation) with the research subjects being fourth grade students of SD Negeri 030355 Parratusan. The results of this development research are appropriate and effective learning media to use. The final result by a material expert is $95 \%$ or in the "Very Eligible" category. Furthermore, the final result from the media expert is 100\% included in the "Very feasible" category, then the results obtained from the fourth grade teacher are $97 \%$ and are included in the "very Eligible" category and at the time of product testing the average score obtained from students is $94 \%$. Then based on the results of the pretest and posttest obtained an increase in student learning outcomes with the achievement of KKM.
\end{abstract}

Keywords: Development, Learning Media, Video Animation, Sparkol Videoscribe.

\begin{abstract}
ABSTRAK
Penelitian ini bertujuan untuk menghasilkan media pembelajaran video animasi berbasis sparkol videoscribe, untuk mengetahui kelayakan media pembelajaran video animasi berbasis sparkol videoscribe dan mengetahui efektifitas penggunaan Media Pembelajaran Video Animasi berbasis Sparkol videoscribe pada Tema 7 Sub Tema 2 Siswa Kelas IV SD Negeri 030355 Parratusan. Penelitian dan pengembangan ini dilaksanakan dengan menggunakan model ADDIE (Analysisi, Design, Development, Implementation and Evaluation) dengan subjek penelitian siswa kelas IV SD Negeri 030355 Parratusan. Hasil penelitian pengembangan ini berupa media pembelajaran yang layak dan efektif untuk digunakan. Hasil akhir oleh ahli materi adalah 95\% atau dalam kategori "Sangat Layak". Selanjutnya hasil akhir dari ahli media adalah $100 \%$ termasuk dalam kategori "Sangat layak" selanjutnya hasil yang diperoleh dari guru kelas IV sebesar 97\% dan termasuk dalam kategori "sangat Layak" dan pada saat uji coba produk ratarata perolehan nilai dari siswa adalah 94\%. Kemudian berdasarkan hasil pretest dan postest diperoleh peningkatan hasil belajar siswa dengan pencapaian KKM.
\end{abstract}

Kata Kunci: Pengembangan, Media Pembelajaran, Video Animasi, Sparkol Videoscribe. 


\section{PENDAHULUAN}

Perkembangan

ilmu

pengetahuan dan inovasi semakin mendorong upaya-upaya pembaharuan dalam pemanfaatan hasil teknologi dalam proses pembelajaran, sehingga meningkatkan mutu pendidikan. Menurut Pribadi (2017, h.1) Teknologi informasi berpengaruh terhadap cara manusia melakukan proses belajar, memperoleh informasi, dan memperoleh pengetahuan. Pemanfaatan teknologi informasi dalam bidang pendidikan difokuskan pada peningkatan kualitas pembelajaran sehingga dapat meningkatkan kualitas pendidikan. Pendidikan merupakan kebutuhan yang sangat penting dalam mengembangkan sumber daya manusia, dan berperan penting dalam menjadikan setiap individu menjadi manusia yang lebih baik melalui proses pembelajaran, yaitu proses interaksi antara guru, siswa, dan sumber belajar.

Pendidikan berperan sebagai salah satu unsur penting dalam pembangunan dan pengembangan bangsa Indonesia. Oleh sebab itu pemerintah berupaya untuk merancang serta mengimplementasikan kurikulum agar kualitas pendidikan semakin baik. Adapun kurikulum yang berlaku di Indonesia saat ini ialah kurikulum 2013. Menurut Krissandi dan Rusmawan (2015, h. 458) kurikulum 2013 pada dasarnya adalah peningkatan dan upaya penyederhanaan dan tematik- integratif yang disiapkan untuk menciptakan generasi yang siap mengahadapi masa depan. Tematik integratif maksudnya ialah pendekatan pembelajaran dari berbagai mata pelajaran kedalam berbagai tema. Kurikulum 2013 dalam proses pembelajarannya mencakup tiga aspek, yaitu aspek sikap (afektif), keterampilan (psikomotor), dan pengetauan (kognitif). Peningkatan dan keseimbangan antara kompetensi sikap, keterampilan, dan pengetahuan didukung oleh strategi guru dalam kegiatan pembelajaran, baik pembelajaran di dalam maupun di luar kelas. Strategi yang dapat digunakan guru dalam kegiatan pembelajaran adalah dengan mengadakan variasi agar dapat meningkatkan minat belajar peserta didik. Salah satu keterampilan dalam mengadakan variasi yaitu dengan menggunakan media pembelajaran yang sesuai dengan perkembangan ilmu pengetahuan danteknologi.

Menurut Kustandy dan darmawan (2020, h.6) media pembelajaran merupakan instrumen yang berfungsi untuk menjelaskan kebermaknaan pesan yang disampaikan saat proses belajar mengajar berlangsung sehingga tujuan pembelajaran tercapai. Hal ini sejalan dengan Sanjaya (2012, h. 15) yang berpendapat bahwa media pembelajaran berfungsi untuk menyajikan materi pembelajaran dan mendorong siswa untuk melakukan berbagai kegiatan sehingga siswa memperoleh wawasan sesuai tujuan pembelajaran. Dengan menggunakan media pembelajaran dapat menarik perhatian siswa untuk belajar lebih aktif dan memperjelas 
makna materi yang disampaikan, sehingga siswa lebih mudah memahami materi pelajaran dan tujuan pembelajaran tercapai.

Namun saat ini media pembelajaran belum dikembangkan sesuai dengan perkembangan ilmu pengetahuan dan Teknologi. Media yang biasa digunakan saat ini hanya media cetak sederhana, media ini kurang menarik sehingga menyebabkan minat belajar siswa berkurang. Media pembelajaran berbasis teknologi seharusnya digunakan saat pembelajaran berlangsung, namun media tersebut masih jarang digunakan dalam proses pembelajaran. Hal ini disebabkan oleh beberapa hal, yaitu ketidak akraban guru dengan teknologi sehingga menyebabkan kesulitan dalam membuat dan merancang media berbasis teknologi, serta sarana prasarana yang belum tersediadi sekolah.

Oleh sebab itu guru hendaknya memiliki pengetahuan yang baik dalam memilih dan merancang media pembelajaran yang menarik dan baik digunakan, untuk meningkatkan pemahaman siswa terhadap materi pelajaran. Di era modern ini sangat tepat jika guru menggunakan media pembelajaran yang sesuai dengan kemajuan teknologi informasi, karena pada dasarnya generasi saat ini tidak lepas dari perkembangan teknologi. Hal ini sejalan dengan Simanjuntak dan Ananda (2018, h. 15) yang berpendapat bahwa sebagai wujud keprofesionalan guru, maka seorang guru dituntut untuk memanfaatkan teknologi dalam proses pembelajaran.

Sebuah keharusan bagi guru agar dapat menggunakan media pembelajaran yang terintegrasi dengan teknologi informasi komunikasi untuk mencapai tujuan pembelajaran. Menurut Wulandari (2016, h. 6) jenis media pembelajaran berbasis teknologi informasi terdiri dari foto, slide, film, video, dan komputer.

Berdasarkan hasil wawancara dengan wali kelas IV yang dilakukan di SDN 030355 Parratusan, diketahui bahwa siswa masih kesulitan memahami materi pelajaran. Hal ini disebabkan karena siswa tidak mendengarkan dengan baik saat guru menjelaskan materi pelajaran. Guru cenderung menggunakan metode ceramah dalam proses pembelajaran karena keterbatasan media pembelajaran. Wali kelas IV berpendapat bahwa kesulitan memahami materi pelajaran dapat diatasi dengan menggunakan media pembelajaran. Namun media pembelajaran yang tersedia dan digunakan hanya media cetak sederhana seperti gambar, poster, kincir, dan media pembelajaran yang dibuat oleh siswa berbentuk kertas origami yang ditempel didalam karton sesuai dengan materi pelajaran yang dibahas. Dengan menggunakan media pembelajaran yang kurang menarik maka minat belajar siswa berkurang sehingga siswa tidak memahami materi yang disampaikan, hal ini diketahui ketika guru bertanya kepada siswa, tidak ada respon dan jawaban dari beberapa siswa. Akan lebih baik di era perkembangan teknologi sekaraang ini, 
media berbasis teknologi digunakan dalam proses pembelajaran. Namun guru belum menggunakan media pembelajaran yang sesuai dengan perkembangan ilmu pengetahuan dan teknologi dikarenakan keterbatasan media yang tersedia di sekolah.

Berdasarkan permasalahan tersebut maka penggunaan media pembelajaran dengan teknologi komputer sebaiknya dapat menjadi alternatif bagi guru untuk memfasilitasi siswa dalam proses pembelajaran. Salah satu media pembelajaran berbasis teknologi komputer yang dapat digunakan untuk memecahkan permasalahan tersebut ialah media pembelajaran berbentuk video animasi. Menurut Pribadi (2017, h. 137) media video merupakan media audiovisual yang dapat menayangkan pesan dan informasi melalui unsur gambar dan suara. Salah satu aplikasi yang dapat membuat media video animasi ialah Sparkol Videoscribe. Pamungkas dan Ihsanuddin (2018, h. 130) berpendapat bahwa sparkol videoscribe merupakan media pembelajaran berbentuk video animasi yang terdiri dari rangkaian gambar dan tulisan yang disusun menjadi video utuh. Sparkol Videoscribe dapat menyajikan konten pembelajaran dengan menggabungkan gambar, suara dan desain yang menarik sehingga mampu meningkatkan efektifitas belajar. Videoscribe merupakan salah satu media yang tepat digunakan untuk berbagi cerita melalui gambar dan teks, sehingga siswa dapat memahami materi pelajaran dengan baik.

\section{METODE PENELITIAN}

Penelitian ini dilakukan di SDN 030355 Parratusan yang terletak di Desa Parratusan Pegagan Julu III Kecamatan Sumbul Kabupaten Dairi. Kelas IV dengan 12 siswa dipilih sebagai kelas penelitian. Penelitian ini dilakukan selama dua bulan. Sumber data dalam penelitian pengembangan ini adalah para ahli yaitu ahli media, ahli materi, guru kelas IV SD, dan siswa kelas IV SD Negeri 030355 Parratusan TA 2020/2021. Dalam pengembangan dan penelitian ini, jenis data yang digunakan adalah data kualitatif dan data kuantitatif. Data kualitatif berupa data analisis permintaan, komentar dan saran dari ahli media dan ahli materi yang diberikan oleh verifikator selama tahap verifikasi produk. Dan data kuantitatif berupa skor dari ahli media, ahli materi, praktisi pendidikan, dan siswa. Model pengembangan yang digunakan dalam penelitian ini adalah model pengembangan ADDIE yang terdiri dari lima tahapan, yakni tahap analisis (analysys), desain (Design), pengembangan (development), implementasi (Implementation), dan evaluasi (evaluation) (Sugiyono, 2017, h. 38-39).

Beberapa instrumen yang digunakan untuk pengumpulan data dalam penelitian ini, yang dikategorikan menurut sumber pengumpulan datanya, antara lain instrumen analisis kebutuhan, 
instrumen peer review, dan instrumen validasi uji lapangan. Instrumen penelitian berupa instrumen wawancara, angket dan alat tes. Instrumen wawancara digunakan untuk menganalisis kebutuhan guru dan siswa dalam penggunaan alat peraga pada siswa kelas IV SD. Kuesioner berisi pernyataan-pernyataan yang disiapkan untuk menguji kegunaan alat peraga yang dibuat oleh peneliti. Instrumen Validasi Kuesioner akan diisi oleh ahli media, ahli materi dan pendidik. Dan alat uji lapangan diisi siswa kelas IV SDN 030355 Parratusan. Kemudian peneliti melakukan analisis kualitatif dan kuantitatif terhadap data yang diperoleh. Setelah data dianalisis maka diketahui kelayakan dan efektifitas media pembelajaran.

\section{HASIL PENELITIAN DAN PEMBAHASAN}

Penelitian ini dilakukan pada masa pandemi Covid-19 mulai pukul 08.00WIB hingga pukul 11.00WIB, sehingga proses pembelajaran dilakukan secara terbatas. Penelitian ini dinamakan ANVIS Video (Animation Based on Sparkle Video Scribe) karena membuat produk media pembelajaran berupa video animasi berbasis Sparkle Video Scribe. Penelitian ini dilakukan dengan model penelitian dan pengembangan model ADDIE. Langkah- langkah penelitian terdiri dari lima tahapan, yaitu analysis (analisis), design (desain), development (pengembangan), implementation (implementasi), evaluation (evaluasi). Berdasarkan hasil wawancara ada analisis kebutuhan, diperlukan media pembelajaran yang sesuai dengan perkembangan teknologi informasi agar pembelajaran semakin menarik dan siswa lebih mudah memahami materi pelajaran.

Berdasarkan analisis perangkat pembelajaran, diketahui bahwa perangkat pembelajaran yang sesuai dengan perkembangan teknologi, mampu menarik perhatian peserta didik dalam melakukan kegiatan pembelajaran. Berdasarkan karakteristik peserta didik dapat diketahui bahwa guru diharapkan lebih mengarahkan pada media pembelajaran sehingga pembelajaran semakin menarik. Kurikulum yang digunakan disekolah ialah kurikulum 2013. Analisis materi dilakukan untuk menentukan produk yang sesuai dengan Kompetensi Inti (KI) dan Kompetensi Dasar (KD) dalam kurikulum. Materi tersebut akan dikembangkan menjadi media video animasi melalui aplikasi sparkol videoscribe sehingga menjadi sumber belajar.

Kemudian media pembelajaran di desain dan dikembangkan oleh peneliti. Setelah itu media pembelajaran di validasi. Validasi dilakukan untuk mengetahui kelayakan media tersebut untuk digunakan. Validasi dilakukan pada tanggal 16 april sampai dengan 28 april. Validasi dilakukan oleh satu dosen ahli materi yang ahli dalam bidang tematik, oleh satu dosen ahli media yang ahli dalam teknologi 
pendidikan, dan oleh praktisi Pendidikan.

Penilaian oleh ahli dilakukan dengan pengisian angket tingkat 1-5.Hasilnya berupa saran dan masukan yang dapat digunakan sebagai dasar untuk memodifikasi media yang dikembangkan, atau sebagai dasar bagi siswa untuk melakukan uji coba produk. Sebelum angket digunakan sebagai alat pengumpulan data, instrument angket telah dikoreksi terlebih dahulu dan dinyatakan layak guna oleh dosen yang ahli dalam bidang Bahasa. Dosen yang mengoreksi angket yang digunakan dalam penelitian ini ialah Ibu Elvi Mailani, S.Si.,M.Pd mengoreksi angket untuk ahli materi, Ibu Masta Marselina Sembiring, S.Pd., M.Pd mengoreksi angket ahli media, dan Bapak Dr. Edizal Hatmi, M.Pd untuk mengoreksi angket praktisi Pendidikan.

Setelah angket dikoreksi kemudian media pembelajaran di validasi oleh ahli materi dan ahli media. Validasi materi dilakukan oleh ahli materi yaitu dosen yang kompeten dibidang materi yang dipaparkan, yaitu dalam pembelajaran tematik. Ahli materi dalam penelitian ini adalah Bapak Fahrur Rozi, S.Pd., M.Pd. Dalam proses validasi yang dilaksanakan dalam penelitian ini, peneliti melakukan 2 kali validasi media sehingga menghasilkan media yang layak untuk digunakan. Validasi pertama dilakukaan pada tanggal 16 april 2021 dan validasi kedua dilakukan pada tanggal 28 april 2021. Validasi media dilakukan oleh ahli media yaitu dosen yang kompeten dibidang teknologi pendidikan. Ahli mediadalam penelitian ini adalah bapak Nur Basuki, S.Pd., M.Pd., M.Pd.T. yang merupakan Master Teknologi Pendidikan. Dalam proses validasi yang dilaksanakan dalam penelitian ini, peneliti melakukan 2 kali validasi media sehingga menghasilkan media yang layak untuk digunakan. Validasi pertama dilakukaan pada tanggal 16 April 2021 dan validasi kedua dilakukan pada tanggal 22 april 2021. Penilaian ini terkait dengan aspek tampilan program, kualitas teknis, aspek Bahasa dankonsep penggunaan.

Media pembelajaran cukup efektif untuk digunakan karena meningkatkan hasil belajar peserta didik dan nilai peserta didik mencapai kriteria ketuntasan minimum. Hal ini dapat dilihat dari meningkatnya ratarata nilai peserta didik dari 60,93 dengan kategori "Cukup" dan kriteria ketuntasan "Tidak Tuntas" meningkat menjadi 89,58 dengan kategori "Baik Sekali" dan kriteria ketuntasan "Tuntas". Oleh sebab itu dapat disimpulkan bahwa media pembelajaran video animasi berbasis sparkol videoscribe layak dan efektif digunakan dalam proses pembelajaran. Setiap tahapan dalam penelitian pengembangan ini sudah terlaksana secara sistematis sesuai dengan tahaptahap model ADDIE.

Pada tahap analisis, peneliti melakukan analisis kebutuhan, analisis perangkat pembelajaran, analisis siswa dan kurikulum, dan analisis materi. 
Peneliti memperoleh data dengan mewawancarai guru kelas IV SD Negeri $030355 \quad$ Parratusan. Berdasarkan analisis kebutuhan, media yang digunakan sangat terbatas dan belum sesuai dengan perkembangan teknologi informasi. Begitu juga dengan perangkat pembelajaran yang digunakan adalah media visual. Kemudian berdasarkan analisis peserta didik, diketahui bahwa siswa menyukai media yang menarik seperti video animasi yang mengandung unsur gambar dan suara. Oleh sebab itu dapat disimpulkan bahwa subjek penelitian membutuhkan media pembelajaran yang sesuai dengan kebutuhan. Sehingga peneliti mengembangkan media pembelajaran video animasi berbasis sparkol videoscribe pada tema 7 sub tema 2 pembelajaran 3 siswa kelas IV.

Tahap kedua adalah tahap desain. Pada tahap ini peneliti telah menyiapkan rencana awal pembuatan media edukasi video animasi berbasis Sparkol Videoscribe. Kegiatan yang dilakukan ialah penyusunan materi yang sesuai dengan kurikulum 2013 yaitu pembelajarantematik Tema 7 Sub Tema 2 Pembelajaran 3 "Keragaman Rumah adat di Indonesia". Kemudian penyusunan bahan-bahan pembelajaran dilakukan, yaitu dengan merancang RPP, kemudian RPP yang telah dibuat divalidasi oleh dosen yang bersangkutan untuk mengetahui ketepatan RPP baik atau tidak digunakan dalam pembelajaran. Bahan pembelajaran diambil dari buku siswa, buku guru dan buku Kemendikbud yang berjudul "rumah adat nusantara untuk siswa kelaas 4, 5 dan 6". Setelah itu instrumen penilaian disusun berbentuk kuesioner dan soal untuk mendapatkan penilaian terhadap kelayakan dan keefektifan media pembelajaran. Kemudian dilakukan pengumpulan dan pembuatan backsound, gambar dan audio. Media pembelajaran di desain sedemikian rupa agar menghasilkan bahan ajar yang layak dan efektif untuk digunakan.

\section{Pembahasan}

Pada Tahap ini peneliti mulai membuat sebuah produk yaitu media pembelajaran video animasi berbasis Sparkol Videoscribe (ANVIS). Dapat dikatakan media video berbasis Sparkol Videoscribe dapat digunakan setelah melalui uji validasi tim ahli materi, tim ahli media, guru kelas IV, dan uji produk. Oleh karena itu, produk divalidasi oleh validator setelah media selesai dibuat.Validator dalam penelitian dan pengembangan ini ialah 1) Fahrur Rozi, S.Pd., M.Pd, sebagai ahli materi, 2) Nur Basuki S.Pd., M.Pd sebagai ahli media, 3) Magda renta Purba, S,.Pd selaku guru kelas IV SD Negeri 030355 Parratusan.

Ahli materi melakukan dua kali validasi untuk menghasilkan media pembelajaran yang sesuai. Validasi ahli materi tahap pertama dilakukan pada tanggal 16 April 2021 dengan skor ratarata 4,00 yang termasuk dalam kategori "baik". Setelah validasi ahli materi tahap kedua pada tanggal 28 April 
2021, skor rata-rata sebesar 4,75 dan termasuk dalam kategori "Baik". Berdasarkan hasil ulangan media verifikasi pada setiap tahapan, hasil ulangan kelayakan media yang diverifikasi oleh ahli materi pada tahap pertama adalah $80 \%$ yang termasuk dalam kategori "Layak", kemudian pada tahap validasi kedua oleh ahli materi diperoleh presentase kelayakan 95\% dan termasuk dalam kategori "Sangat Layak".

Validasi oleh ahli media dilakukan sebanyak dua kali agar media pembelajaran lebih baik. Validasi pertama dilakukan oleh ahli media pada tanggal 16 april 2021 dengan perolehan nilai ratarata 4,25 dan termasuk dalam kategori "Sangat Baik". Kemudian setelah dilakukan vealidasi kedua oleh ahli media pada tanggal 22 April 2021 didapatkan nilai ratarata sebesar 5,00 dan termasuk dalam kategori "Sangat Baik". Berdasarkan hasil rangkuman validasi media dari setiap tahap, hasil rangkuman kelayakan media oleh ahli media pada tahap validasi pertama adalah $85 \%$ termasuk dalam kategori "Sangat Layak", kemudian pada validasi tahap kedua diperoleh presentase kelayakan $100 \%$ dan termasuk dalam kategori "Sangat Layak".

Implementation Pada tahap ini media pembelajaran yang dinyatakan layak oleh validator di uji coba kepada siswa kelas IV SD Negeri 030355 Parratusan untuk mengetahui respon siswa terhadap kelayakan media pembelajaran, serta untuk mengetahui peningkatan hasil belajar siswa. Subjek penelitian ini terdiri dari 12 siswa kelas IV SD Negeri 030355 Parratusan. Melalui peningkatan hasil belajar siswa maka media pembelajaran dapat dikatakan efektif. Untuk melihat peningkatan tersebut dilakukan pre-test sebelum menggunakan media pembelajaran dan postest setelah menggunakan media pembelajaran video animasi berbasis sparkol videoscribe. Berdasarkan uji coba produk yang dilakukan, uji kelayakan media dengan melihat rekapitulasi hasil respon peserta didik dapat diketahui bahwa rata-rata presentase kelayakan yang diperoleh oleh peserta didik adalah 94\% dan termasuk dalam kategori "Sangat Layak". Uji keefektifan media dapat diketahui bahwa hasil belajar siswa meningkat setelah menggunakan media pembelajaran video animasi berbasis sparkol videoscribe. Saat pre-test nilai rata-rata siswa mencapai 60,83 dan termasuk dalam kategori "Cukup" dan kriteria ketuntasan "Tidak tuntas" namun setelah menggunakan media pembelajaran, nilai rata-rata siswa meningkat menjadi 89,58 dengan kategori "Sangat Baik" dan kriteria ketuntasan"Tuntas".

Evaluation Media pembelajaran yang dihasilkan layak dan efektif untuk digunakan karena telah di validasi oleh ahli media, ahli materi, dan uji coba lapangan. Media pembelajaran Video Animasi berbasis sparkol videoscribe termasuk dalam kategori "Sangat Layak" dengan rata-rata rekapitulasi dari ahli materi, ahli media, pendidik 
dan uji coba lapangan sebesar $96,5 \%$. Selain layak untuk digunakan media pembelajaran Video Animasi berbasis sparkol videoscribe efektif untuk digunakan dengan nilai rata-rata siswa 60,83 meningkat menjadi 89,58 dengan kategori "Sangat Baik" dan kriteria ketuntasan "Tuntas". Pengembangan media pembelajaran video ini diperkuat dengan penelitian terdahulu oleh Indyra Fransiska dan Mintohari yaitu penelitian tentang pengembangan media pembelajaran berbasis sparkol videoscribe tentang pelajaran IPA Kelas VI SD dalam materi tata surya, berdasarkan hasil penelitian tersebut diketahui bahwa media layak digunakan dalam pembelajaran setelah melakukan validasi terhadap ahli materi, validasi ahli media dan uji coba lapangan. Begitu juga dengan penelitian oleh Munida Quonita Silmi dan Putri rachmadyanti yaitu penelitian pengembangan media pembelajaran berbasis Sparkol videoscribe tentang kesiapan kemerdekaan RI kelas V, dalam hal ini dapat diketahui bahwa media video sparkol videoscribe dapat digunakan dalam berbagai mata pelajaran baik itu untuk pelajaran IPA maupun tematik, hal ini diperkuat dengan kelayakan media oleh Munide Silmi dan Putri berdasarkan tingkat kelayakan yang diperoleh setelah validasi dari ahli materi dan ahli media serta uji coba terhadap peserta didik. Penelitian oleh poza, zampel dan Sudarma dengan pengembangan media video animasi pada pembelajaran siswa kelas IV juga memperkuat penelitian ini. Dalam hal ini diketahui bahwa media pembelajaran layak dan efektif digunakan setelah divalidasi oleh ahli isi, ahli desain, ahli media serta di uji cobakan langsung kepada peserta didik.

\section{SIMPULAN}

Berdasarkan penelitian dan pengembangan yang dilakukan oleh peneliti maka simpulan yang dapat diperole yaitu Penelitian dan pengembangan ini dilaksanakan dengan menggunakan model ADDIE (Analysisi, Design, Development, Implementation and Evaluation) dengan subjek penelitian siswa kelas IV SD Negeri 030355 Parratusan. Hasil penelitian pengembangan ini berupa media pembelajaran yang layak dan efektif untuk digunakan. Hasil akhir oleh ahli materi adalah 95\% atau dalam kategori "Sangat Layak". Selanjutnya hasil akhir dari ahli media adalah $100 \%$ termasuk dalam kategori "Sangat layak" selanjutnya hasil yang diperoleh dari guru kelas IV sebesar 97\% dan termasuk dalam kategori "sangat Layak" dan pada saat uji coba produk rata- rata perolehan nilai dari siswa adalah 94\%. Kemudian berdasarkan hasil pretest dan postest diperoleh peningkatan hasil belajar siswa dengan pencapaian KKM. Maka dapat disimpulkan bahwa media pembelajaran video animasi berbasis sparkol videoscribe tapa Tema 7 Subtema 2 bahwa siswa kelas IV SD 
Eva Betty Simanjuntak, Astria Hospital Tampubolon : Pengembangan Media ....

Negeri 030355 Parratusan dapat dikembangkan dan layak serta efektif digunakan sebagai media pembelajaran.

\section{DAFTAR RUJUKAN}

Krissandi, Apri \& Rusmawan. 2015. Kendala Guru Sekolah Dasar Dalam Implementasi Kurikulum 2013. Cakrawala Pendidikan. 3(xxxiv):458.

Kustandy, cecep \& Darmawan, Daddy. 2020. Pengembangan Media Pembelajaran. Jakarta: Kencana.

Pamungkas \& Ihsanuddin. 2018. Video Pembelajaran

Berbasis

Videoscribe: Sparkol

Perkuliahan Inovasi

Matematika. Prima: Jurnal Pendidikan Matematika. 2(2):130.

Pribadi, A Benny. 2016. Desain dan Pengembangan Program Pelatihan berbasis Kompetensi Implementasi Model ADDIE. Jakarta: Pernada Media Group.

Pribadi, A Benny. 2017. Media dan Teknologi dalam Pembelajaran. Jakarta: Kencana.

Sanjaya, Wina. 2012. Media Komunikasi Pembelajaran. Jakarta: Prenadamedia Group.

Sanjaya, Wina. 2013.
Perencanaan dan Desain Sistem Pembelajaran. Jakarta: Kencana. Simanjuntak, Eva Betty \& Ananda, Nurul. 2018. Pengaruh Penggunaan Game Edukasi Interaktif "Tematik" Berbasis Macromedia Flash Terhadap Hasil Belajar Tema 4 Berbagai Pekerjaan Kelas IV SDN 028229 Binjai Barat Tp 2017/2018. Jurnal Guru Kita (JKG). Vol. 2(3). 15. Siswono, Tatag Yuli Eko. 2019. Paradigma Penelitian Pendidikan. Bandung: Remaja Rosdakarya.

Sugiyono. 2017. Metode Penelitian dan Pengembangan Research and Development. Bandung: Alfabeta.

Wulandari, Dyah Ayu. 2016. Pengembangan Media Pembelajaran Menggunakan Sparkol Video Scribe dalam meningkatkan Minat Belajar Siswa pada Mata Pelajaran IPA Materi Cahaya Kelas VIII di SMP Negeri 01 Kerjo Tahun Ajaran 2015/2016. (Skripsi). Semarang: Universitas Negeri Semarang. 